\title{
Performance Assessment of Partnership Estate Surveying and Valuation Firms in Lagos State, Nigeria Oloke Olayinka Clement
}

\author{
Department of Estate Management, College of Science and Technology, \\ Covenant University, Ota, Ogun State \\ c_yinkaoloke@yahoo.com
}

\author{
ljasan Kolawole Clement (Ph.D) \\ School of Construction Economics and Management, \\ Faculty of Engineering and the Built Environment, \\ University of the Witwatersrand, 1 Jan Smuts Avenue, Braamfontein, \\ Johannesburg 2050, South Africa ijasank@yahoo.com
}

\section{Oyedele Bamidele Joseph (Ph.D)}

Department of Estate Management, Faculty of Environmental Design and Management, Obafemi Awolowo University, Ile-Ife, Osun State Joe_christ2001@yahoo.co.uk

\section{Doi:10.5901/mjss.2013.v4n13p489}

\section{Abstract}

This study advances the understanding of the relationship between firm size and performance on partnership formation and sustainability in the profession of Estate Surveying and Valuation in Nigeria. It has been argued in different literatures that size is positively related to performance for some categories of firms but negatively related in some other cases. This study examines the opinion of both the sellers and buyers of real estate services on the subject. Questionnaires were administered to 68 respondents selected from sole proprietorship estate firms, partnership estate firms and commercial banks in Lagos Metropolis. Data were presented and analysed with frequency tables, percentages, 4-point Likert scale and relative importance index. Findings reveal that the performance assessment criteria used by the sellers differ from those engaged by the buyers and that partnership estate firms record better performance from both side. It was further revealed that the overall performance assessment score partnership better than sole proprietorship estate firms. It is therefore concluded that performance could not have been a factor militating against partnership formation and sustainability in Estate Surveying and Valuation in Nigeria. The study suggest that prospective partners and the Nigeria Institution of Estate Surveyors and Valuers should come up with ethics and code of practice particular to partnership whereby erring partners face disciplinary action at the institution and compelled to compensate the other partner(s) and the firm by forfeiting certain benefits.

Keywords: estate valuers, partnership, firm size, performance, sustainability

\section{Introduction}

The relationship between firm size and its performance has received considerable attention in the literature and has provoked vigorous debate (Symeou, 2011). The size of a firm affects performance in many ways. Some argued that large firms are more likely to exploit economies of scale and enjoy higher negotiation power over their clients and suppliers (Serrasqueiro and Macas Nunes, 2008; Mansfield, 1962; Singh and Whittington, 1975). Penrose (1959) in Majumdar (1997) highlighted key features of large firms as its diverse capabilities, the abilities to exploit economies of scale and scope and the formalization of procedures. These characteristics according to Penrose allow larger firms to generate superior performance relative to smaller firms, by making the implementation of operations more effective. In addition, Yang and Chen (2009) opined that larger firms face less difficulty in getting access to credit for investment, have broader pools of qualified human capital, and may achieve greater strategic diversification. Meanwhile, Pugh et al. (1969) and Child (1973), among others, showed that size leads to bureaucracy and that large firms are usually highly 
bureaucratised. Blau and Meyer (1987) classified the diseconomies of bureaucracy into three major categories: (1) excessive rigidity, (2) conservatism/resistance to change, and (3) perpetuation of social-class differences. Other diseconomies of scale resulting from negative consequences of firm size as identified by Williamson (1975) include atmospheric consequences due to specialisation, incentive limits of the employment relation and communication distortion due to bounded rationality.

On the other hand, small firms according to Symeou (2011) exhibit certain characteristics which can counterbalance the handicaps attributed to their smallness. Yang and Chen (2009) also opined that small firms suffer less from the agency problem and are characterised by more flexible non-hierarchical structures, which may be the appropriate organisational forms in changing business environments. Alternative view suggest that size is correlated with market power (Shepherd, 1986) and that along with market power, a level of inefficiencies are developed leading to relatively inferior performance (Leibenstein, 1976). Thus, theory has been equivocal on the precise relationship between size and performance (Symeou, 2011) and existing empirical evidence has been lending support to both positive and negative impact of firm size on performance (Majumdar, 1997). The relationship between firm and size has been defined from different points of view. Penrose $(1959,1995)$ and Arrow $(1974)$ see size as the point where transactions are regulated by the market rather than by administration. Hart (1995) see firm size in terms of its ownership and therefore define it as the combination of activities for which the bearers of residual risk are one and the same. Richardson 1972 sees firm size beyond its corporate ownership and defines it as a network of franchise. Williamson (1985) opined that the size of a firm is based on the firm's sphere of influence and this includes distributors, alliance partners, first- and secondtier suppliers, and etc. In this study, Harts' (1995) definition and Richardson (1972) would be adopted. Firm size would therefore be examined from the perspective of ownership, employee and network of branches.

In the same vein, performance, which shows if the resources of the firm are used efficiently to fulfill the goals of the firm (Daft, 1997), is crucial in evaluating the overall success of the firm (Parker, 2000). In evaluating firms' performance, authors have identified different measures. For instance, Topak (2011) stated that firms engage both financial and nonfinancial criteria and that financial performance measures are the starting point for most organizations' performance measures systems (Bloxham, 2002). In the view of Majumdar (1997), the economic performance of firms is captured using two measures, productivity and profitability. Citing the precedent set by the Organization for Economic Cooperation and Development [OECD] (1994), productivity is measured as the ratio of value added to the value of production and according to the industrial organization and management literatures (Cowling and Waterson, 1976; Capon et al., 1990) profitability is measured as returns on sales, or the margin on sales. This study identifies the criteria for performance measurement of estate firms whilst their opinion on firms' performance is also obtained on profitability and productivity.

\section{Statement of Problem}

Partnership in business is considered more beneficial compared to sole proprietorship because of the numerous advantages embedded in it. Some of these according to Ford et al, (2003) include capital contribution, flexibility, shared responsibility, joint decision making, partners' family sustainability and business continuity. Kuye (2011) also highlighted other benefits of partnership as innovation, increased customer satisfaction, stability, cost effectiveness, efficiency, etc. Despite the benefits of partnership, it is observed that Estate Surveyors and Valuers in Nigeria have not embraced partnership. Citing Kuye, (2011) "the percentage of partnership firms in Estate Surveying and Valuation profession is really very low in Nigeria. With most estate firms as sole proprietorship, the profession's growth is slow and their activities are limited to the country as only few of the estate firms can afford to have their branches in other countries". The author further observed that the nature of Estate Surveying and Valuation profession requires the coming together of Estate Surveyors and Valuers to form partnership thereby improving the quality of services rendered. Apart from the challenges and disadvantages associated with partnership, this study also examines whether performance discourages partnership formation and sustainability in the profession.

\section{Literature Review}

\subsection{Forms of Business Ownership}

A business is a vital seed of societal development and an avenue for economic and financial independence for its owner. Hence its sustained practice and performance constitute a major concern to the owner. According to Gradl \& Jenkins (2011), one of the greatest contributions that business can make to society is to expand access to goods, services, and 
economic opportunities. For businesses to maximise their contribution to development, there is the need for periodic evaluation of business plans and practices. This would ultimately engender business practice innovation for long-term sustainability and broad multi-stakeholder collaborations to remove systemic barriers to scale and impact (Gradl \& Jenkins, 2011). The link between firm performance and ownership is often viewed as going through the interaction and power distribution between the owners and managers of firms. Business ownership as noted by Kocenda and Svejnar (2003) have been simply treated as private, state, foreign, domestic private outsider, domestic private insider without stating the exact number of individuals thereby obfuscating the influence or desirability of concentrated or dispersed ownership on business performance.

Modern literatures as well as the legal system of different countries have recognised the following categories of business entity; sole proprietorship, partnership, cooperatives, corporation, private and public limited liability company, unlimited liability company as well as company limited by guarantee (e.g. South-Africa's Companies Act 71 of 2008, the Nigeria's Companies and Allied Matters Act, 1990). According to the South-Africa Business Guide, the numbers of owners of each of these business entity ranges from one as in the case of sole ownership, minimum of one in close corporation, private company, personal liability company, public company and state owned company, minimum of two in partnership, minimum of three in non-profit companies and minimum of five in cooperatives. Apart from sole proprietorship, it is apparent that other business entities have the capacity of being owned by one or more persons while the maximum number of owners is determined by the business policy and moderated by the country's legal system.

\subsection{Measure of Firm Size}

The size of a firm is measured in various ways. As noted by Camback, Samouel and Price (2006), size is most often defined as annual revenue especially by the business press. The author further revealed that this measure is basically meaningless because it tells nothing about the depth of the underlying activity. Using this measure however, the world's four largest companies were Japanese trading houses in 1994 (Fortune, 1995b). They had between 7,000 and 80,000 employees, but almost no vertical integration. A better measure of size is value added, which is more or less equivalent to revenue less externally purchased products and services. This metric gives a precise measure of activity, but it is usually not publicly available for individual firms (Camback, Samouel and Price, 2006). Number of employees is the most widely used measure of size. From the viewpoint of Child's (1973), size is a function of the people in a firm and that the number of employee is the most used metric for measuring firm size. According to Kimberley (1976), more than 80 per cent of academic studies use this measure. Grossman and Hart (1986) expressed size in terms of assets. Camback, Samouel and Price, (2006) concluded that the best measures of size are value added and number of employees, although assets can be used in certain types of studies. This study uses ownership, spread and employee as size metric because of their direct influence on both decision-making and job execution in the firm.

\subsection{Partnership}

Partnership is the coming together of two or more people in a contractual agreement with a common aim to establish a business enterprise. It is a strategic alliance, a relationship based on trust, equality mutual understanding and obligation (Kuye, 2011). Partnership involves combination of ideas and resources for the success of the organization. A partnership is said to be a voluntary contract between two or among more than one persons to place their capital, labour and skills in business with the understanding that there will be a sharing of the profits and losses among partners. The Real Estate Dictionary (2004) defines partnership as an agreement between two or more entities to go into business or invest. According to the Financial \& Investment Dictionary (2006), a partnership is defined as a contract between two or more people in a joint business who agree to pool their funds and talents and share in the profits and losses of the enterprise.

A partnership could be general or limited. General partnership is formed when two or more people come together to carry on a business activity. The distinguishing feature of this partnership is the unlimited liability of the partners. Each partner is personally liable for all of the debts of the partnership. That includes any debt incurred by any of the two other partners on behalf of the partnership. Either partner is able to bind the partnership by entering into a contract on behalf of the partnership. Furthermore, all the partners possess equal contractual power, share the risks and proceeds of the business equally. Also, each of them is actively involved in the running of the business each having equal responsibilities. A limited partnership on the other hand consists of one or more general partners and/or more limited partners (Kuye 2011). The same person can be both a general partner and a limited partner as long as there are two legal persons who are partners in the partnership. The general partner is responsible for the management of the affairs of 
the partnership and he has unlimited personal liability for all debts and obligation. Limited partners have no personal liability. He only stands to loose only the amount which he has contributed and any amounts which he has obligated himself under the terms of the partnership (Kuye, 2011).

\subsection{Partnership Real Estate Firm}

A partnership is defined by the British Partnership Act 1890 as the relationship which exists between persons carrying on a business in common with a view of making profit. In Nigeria, Partnerships are regulated by the British Partnership Act of 1890 while the Companies and Allied Matters Act 1990 of Nigeria regulate the operations of companies and limit the number of people allowed in a partnership to twenty except in partnership formed by lawyers and accountant (see section 19(3) of CAMA 1990). According to section 19(3) of the Companied and Allied Matters Act, it is illegal to form a partnership of more than 20 persons (except partnership of certain professionals like Accountants and Lawyers) With regard to real estate business, partnership occurs when two or more qualified and registered Estate Surveyors and Valuers come together to establish and operate one real estate business with a common goal and target (Kuye, 2011). In the Estate Management parlance, partnership simply means a contractual arrangement between individuals with a common goal and objective to carry on real estate business activities. The document signed by all parties who enter into a partnership is referred to as partnership deed (Kuye, 2011).

\subsection{Estate Surveyor and Valuer}

Otherwise referred to as an appraisal in the United States, a valuer in Australia and a surveyor in most commonwealth countries, an estate surveyor and valuer is one qualified, recognized and duely authorized by law in Nigeria to carryout valuation and other real estate services. The International Valuation Standards Council (IVSC, 2005) describes a valuer as "a person who possesses the necessary qualifications, ability and experience to execute valuation". He is one that has been duly registered by the Estate Surveyors and Valuers Registration Board of Nigeria (ESVARBON) as recognised under CAP 111, LFN of 1990 and is charged with the responsibilities of directing and supervising of interests in landed properties and carrying out the practice of estate management in general while adhering to requisite professional ethics. ESVARBON is the government supervisory body that monitor and moderate the practice while the Nigerian Institution of Estate Surveyors and Valuers (NIESV) is the institutional administrative body that establish standard of practice, improve technical knowledge and facilitate knowledge dissemination among practitioners amongst other responsibilities. The NIESV was founded in 1969 and incorporated under the Land Act, Chapter 98 Laws of Nigeria in 1970. The institution was further recognised by law in 1975 via Decree No. 24 of 1975 now CAP 111, Laws of the Federation of Nigeria 1990(Kuye, 2008).

The various functions of an estate surveyor and valuer include Estate Agency, Property Management, Project Development and Management, Estate Consultancy Services, Arbitration Services, Property Rating, Compensation and Compulsory Acquisition Matters, Land Economy/Management, Valuation, Facilities Management, Development Feasibility and Viability Appraisal, Auctioneering (Kuye, 2008; Ifediora, 2009). A typical organisation structure of an estate firm is shown in Figure 1.

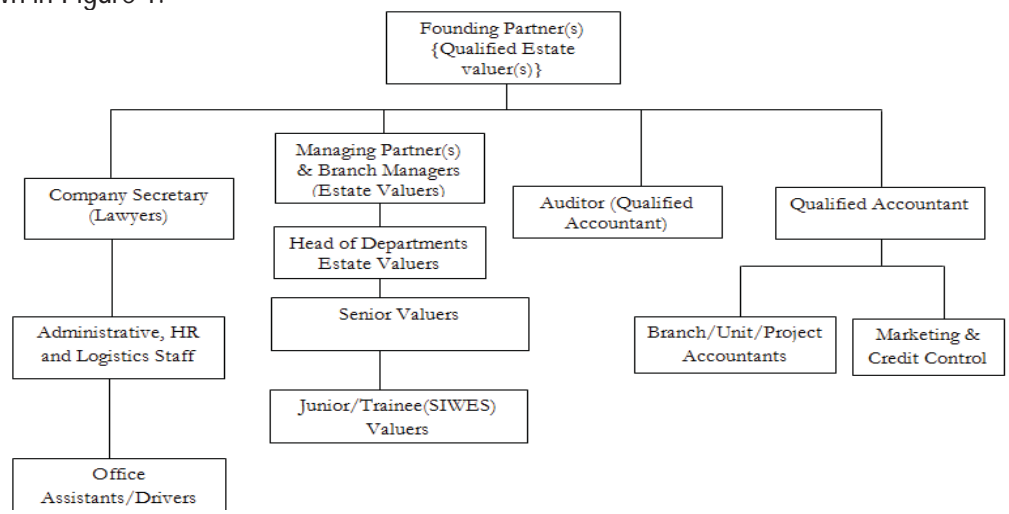

Figure 1. A Typical Organisational Structure of an Estate Firm 


\section{Research Methods}

This study reviewed relevant literature that provides the conceptual basis. Primary data were obtained with questionnaires from three strata of respondents that constitute the study population. The study population is the 314 registered estate surveying and valuation firms in Lagos State (NIESV LAGOS, 2012) and the 25 consolidated banks in Nigeria with operational head or regional offices in Lagos State. Respondents were drawn from the 302 sole proprietorship and 12 partnership estate firms and banks that constitute major corporate buyers of real estate services in Nigeria. Chosen among each stratum of respondents include

i. 38 firms randomly selected from the 302 registered sole proprietorship estate firms,

ii. All the 12 partnership estate firms

iii. 18 banks randomly selected from the 25 consolidated banks

The overall sample size is therefore the 68 respondents chosen from the three cadres of respondents. Questionnaires were administered to top management staff of the Estate Surveying and Valuation Firms to elicit information on the nature of business entity, size of ownership, technical capability, services, size of employee, network of offices and turnover. Information sought from buyers' group were focussed on the level of satisfaction with the services provided by the consultant firms, competence, adequacy of manpower and other technical resources as well as financial capability of the firm. Data collected were analysed with frequency tables, percentages, 4-point Likert scale and relative importance index.

\section{Data Presentation and Analysis}

Table 1. Rate of Response

\begin{tabular}{lccc}
\hline \multicolumn{1}{c}{ Study Group } & Sample size & Response & Percentage (\%) \\
\hline Sole Proprietorship & 38 & 35 & $92 \%$ \\
Partnership & 12 & 10 & $83 \%$ \\
Commercial Banks & 18 & 15 & $83 \%$ \\
Total & 68 & 60 & $88 \%$ \\
\hline
\end{tabular}

Source: Authors' Field Survey 2013

Questionnaire was targeted at top management staff of estate firms such as the Principal Partners, Branch Managers or Head of Departments who are at least an Associate of the Nigeria Institution of Estate Surveyors and Valuers. For the banks, questionnaires were directed to Head of Property department, risk and investment departments who are all deemed to have acquired relevant education and experience to hold such posts. In all 68 questionnaires were administered to 38 sole proprietorship estate firms, 12 partnership estate firms and 18 commercial banks in Lagos State. Analysis of questionnaires retrieved as in Table 1 shows 35(92\%) response rate from sole proprietorship estate firms, $10(83 \%)$ rate of response from partnership estate firms and $15(83 \%)$ from the commercial banks. The level of response is sufficient for subsequent analysis.

Table 2. Characteristics of the Respondent Firms

\begin{tabular}{cccccccc}
\hline \multicolumn{2}{c}{ No of Founders } & \multicolumn{2}{c}{ Years of Operation } & \multicolumn{2}{c}{ No of Offices } & \multicolumn{2}{c}{ No of Key Staff } \\
\hline No & Firms & Years & Firms & Offices & Firms & Staff & Firm \\
\hline 1 & $35(78 \%)$ & $1-10$ & $11(24 \%)$ & 1 & $6(13 \%)$ & $1-10$ & $3(7 \%)$ \\
$2-4$ & $7(15 \%)$ & $11-20$ & $15(33 \%)$ & $2-7$ & $17(38 \%)$ & $11-35$ & $19(42 \%)$ \\
$5-9$ & $3(7 \%)$ & $21-30$ & $12(27 \%)$ & $8-15$ & $15(33 \%)$ & $35-70$ & $14(31 \%)$ \\
Above 9 & - & Above 30 & $7(15 \%)$ & Above 15 & $7(16 \%)$ & Above 70 & $9(20 \%)$ \\
Total & 45 & & 45 & & 45 & & 45 \\
\hline
\end{tabular}

Source: Author's Field Survey 2013

The characteristics of the respondents' estate firms were gathered and presented in Table 2. Apart from the 35 sole proprietorship firms, 7 firms indicate between 2and 4 co-owners and 3 indicate between 5 and 9 co-founders. Although, the geographical spread of the offices is not required, the number of offices as in table 2 shows that majority $17(38 \%)$ 
has between 2 and 7 offices including the head office. The table further show that 19 firms have between 11 and 35 staff trained to carryout estate surveying and valuation tasks.

Table 3. Criteria for Performance Measurement by the Firm

\begin{tabular}{lcccc}
\hline \multicolumn{1}{c}{ Criteria for performance measurement } & \multicolumn{2}{c}{ No of Firms } & Total & Percentage \\
\hline & Sole Estate Firm & Partnership Estate Firm & Total & \\
\hline No of Job brief secured & 26 & 10 & 36 & $80 \%$ \\
No of Job successfully Executed & 14 & 3 & 17 & $38 \%$ \\
Base/previous year Comparison & 35 & 10 & 45 & $100 \%$ \\
Measurement against Benchmark/Target & 29 & 8 & 37 & $82 \%$ \\
Annual Profit & 35 & 10 & 45 & $100 \%$ \\
Market penetration & 16 & 7 & 23 & $51 \%$ \\
\hline
\end{tabular}

Source: Author's Field Analysis 2013

Respondents were also asked to indicate the criteria used by their firms to assess performance level. Responses are analysed and presented in table 3 and shows that all the firms indicate the use of comparison with previous year and annual profit. It is also showed that majority $36(80 \%)$ and $37(82 \%)$ also indicate the use of no of job instruction secured and benchmark respectively. The least used criterion is the number of job successfully executed while the level of market coverage is applied by about $51 \%$ of the estate firm surveyed. It was however observed that the use of each criterion is without dichotomy.

Table 4. Criteria for Performance Measurement by Banks

\begin{tabular}{lccccccccc}
\hline \multicolumn{1}{c}{ Criteria for performance Measurement } & No of banks & \multicolumn{2}{c}{ Weight } & & Total & RII & Position \\
\hline Record of past jobs & & 4 & 3 & 2 & 1 & & & \\
Value of Past Jobs & $15(100 \%)$ & 48 & 9 & 0 & 0 & 57 & 3.80 & $1^{\text {st }}$ \\
Availability of Qualified resource personnel & $8(53 \%)$ & 16 & 12 & 0 & 7 & 35 & 2.33 & $7^{\text {th }}$ \\
Access to finance & $13(87 \%)$ & 24 & 21 & 0 & 0 & 45 & 3.00 & $4^{\text {th }}$ \\
Proof of Ownership/Access to Requisite Equipment & $10(66 \%)$ & 12 & 9 & 8 & 5 & 34 & 2.27 & $8^{\text {th }}$ \\
Timely and satisfactory job completion & $12(80 \%)$ & 12 & 15 & 8 & 3 & 38 & 2.53 & $6^{\text {th }}$ \\
Number of owners & $15(100 \%)$ & 40 & 15 & 0 & 0 & 55 & 3.67 & $2^{\text {nd }}$ \\
Number of staff & $3(20 \%)$ & 0 & 0 & 6 & 12 & 18 & 1.20 & $10^{\text {th }}$ \\
Number/spread of offices & $15(100 \%)$ & 12 & 21 & 10 & 0 & 43 & 2.87 & $5^{\text {th }}$ \\
Work plan/Methodology of Implementation & $7(46 \%)$ & 8 & 9 & 4 & 8 & 29 & 1.93 & $9^{\text {th }}$ \\
\hline
\end{tabular}

Source: Author's Field Analysis 2013

From the perspectives of the quality of service rendered to commercial banks, respondents from the surveyed institutions were asked to indicate the criterion used to assess the performance of the estate firms. As shown in table 4, the first indicator of the capability of an estate firm whether sole or partnership is the record of work experience. Further assessment criteria include timely and satisfactory completion of jobs as indicated by $100 \%$ of respondents from bank, availability of qualified and experienced personnel (87\%), ownership or access to requisite equipment (80\%), detailed work plan (73\%), access to finance(66\%). It is observed that only $3(20 \%)$ showed interest in the use of number of owners as a criterion for performance assessment. However, the relative importance index showed that the criterion is of little relevance with its last $\left(10^{\text {th }}\right)$ position among other criteria being used by these firms.

Table 5. Performance Assessments of Estate Firms by Estate Valuers

\begin{tabular}{lccc}
\hline & Sole Estate Firms & Partnership Estate Firms & Total \\
\hline Highly satisfactory & $6(17 \%)$ & $4(40 \%)$ & $10(22 \%)$ \\
Satisfactory & $16(46 \%)$ & $5(50 \%)$ & $21(47 \%)$ \\
Less satisfactory & $9(26 \%)$ & $1(10 \%)$ & $10(22 \%)$ \\
Not satisfactory & $4(11 \%)$ & 0 & $4(9 \%)$ \\
Total & $35(100 \%)$ & $10(100 \%)$ & $45(100 \%)$ \\
\hline
\end{tabular}

Source: Author's Field Analysis 2013 
Table 5 provide the performance assessment of their respective estate firms. Analysis of data shows similar trend in performance assessment of both sole proprietorship and partnership estate firms. A total of 22(49\%) respondents from estate firms are of the opinion that the performance of the firms is satisfactory while 10(22\%) are of the opinion that the performance is either highly satisfactory or less satisfactory respectively. However, it was noted that the $7 \%$ of respondents that indicated unsatisfactory performance emanates from the sole proprietorship estate firms alone.

To further affirm this view, similar survey of opinion was carried out among respondents from estate firms and commercial banks. Respondents were requested to indicate their opinion as regards whether they agree that partnership estate firms are better performers than sole estate firms. Table 6 shows that 30(50\%) out of the overall respondents agree that partnership estate firms perform better than sole estate firms. This is made up of the 23(51\%) of respondents from estate firms and $7(47 \%)$ of respondents from commercial banks. It is also observed that $14(23 \%)$ of the overall respondents which is made up of $9(20 \%)$ respondents in estate firms and 5(33\%) from commercial banks are indifferent to the performance.

Table 6. Overall Performance Assessments of Partnership Estate Firms

\begin{tabular}{lcccc}
\hline Respondent group & Yes & No & Indifferent & Total \\
\hline Estate Surveyors & $23(51 \%)$ & $13(29 \%)$ & $9(20 \%)$ & 45 \\
Banks & $7(47 \%)$ & $3(20 \%)$ & $5(33 \%)$ & 15 \\
Total & $30(50 \%)$ & $16(27 \%)$ & $14(23 \%)$ & 60 \\
\hline
\end{tabular}

Source: Author's Field Analysis 2013

\section{Results and Discussion}

The importance of sustainable partnership to the practice of estate surveying and valuation cannot be over-emphasised. Yet, over the years, the reluctance of qualified individuals to form partnership and dissolution of those existing has being a serious challenge. According to the Lagos Branch of the Nigeria Institution of Estate Surveyors and Valuers, there are only 12 partnership firms out of the 314 estate firms existing in Lagos State as at 2012. In order to carry out a holistic assessment, both the sellers and buyers opinions were sought. This includes all the 12 partnership firms, 38 randomly selected sole proprietorship and 18 randomly selected commercial banks. The response rate of $88 \%$ made data collected sufficient and result of analysis reliable. Table 2 further reveals partnership size in terms of the number of founding partners, offices and key staff. The number of partners that formed an estate firm ranges between 2 and 9 . It is observed that the number of key staff does not necessarily depend on the number of founding partners but firm size and spread and could be as few as less than 10 and as high as 70 and above.

Furthermore, various criteria used by the respondent firms and commercial banks to assess their performances were identified in tables $3 \& 4$. It is observed that though the overall annual profit and base year comparison are commonly used by all the estate firms, the performance of each department or unit of the firm are also assessed on monthly, quarterly and annual basis using criteria such as the number of job brief secured, number of successful implementation, market penetration and target. This thus implies that these firms consistently review their performances and therefore make necessary adjustment. From the buyers' point of view, the criteria for performance assessment were identified and ranked according to their level of importance and usage. It is observed that though, record of past jobs, timely and satisfactory completion of jobs and staff capacity are used by most buyers but ranked $1^{\text {st }}, 2^{\text {nd }}$ and $5^{\text {th }}$ on the relative importance index table. Other criteria variously used include work plan which ranked $3^{\text {rd }}$, qualified resource personnel which ranked $4^{\text {th }}$, ownership/access to requisite equipment which ranked $6^{\text {th }}$ and value of past jobs which ranked $7^{\text {th }}$. It is observed however that though office spread and number of owners featured among the criteria, least importance is attached to them and thus ranked $9^{\text {th }}$ and $10^{\text {th }}$ respectively on the relative importance index.

Having established that performance assessment is carried out by each study group, respondents in estate firms were further requested to express their opinion on the overall performance assessment of their respective firms. The analysis shows that $40 \%$ of partnership estate firms indicate highly satisfactory performance as against $17 \%$ of sole proprietorship estate firms. Also $50 \%$ of partnership estate firms indicate satisfactory performance compared to the $46 \%$ by sole proprietorship. This is also reflected in the percentage of estate firms that records less satisfactory performance which is $10 \%$ in partnership against the $26 \%$ in sole proprietorship. The trend simply shows that partnership estate firms perform better than sole proprietorship firms. This is further reaffirmed in table 6 where general opinion indicate that 
$30(50 \%)$ out of the overall respondents agree that partnership estate firms perform better than sole estate firms and $16(27 \%)$ are of contrary opinion. Only $14(23 \%)$ of the overall respondents are indifferent to the performance.

\section{Concluding Remarks}

This study examines the performance of estate firms particularly partnership estate firms in an attempt to broaden practitioners perception and assist decision making about its formation and sustainability. The impact that the number of principal partners could have on overall performance of an estate firm was examined. The overall opinion shows that partnership estate firms perform better than sole proprietorship estate firms. This therefore corroborates the observation that partnership has more advantages over sole proprietorship. This also eliminates any assumption that performance could be a major factor militating against the formation and sustainability of partnership in the profession of Estate Surveying and Valuation. It is therefore suggested that practitioners of the profession as well as the Nigeria Institution of Estate Surveying and Valuation come up with ethical standards and code of conducts specific to partnership that will deter prospective partners from taking action that could undermine the alliance. The bane of partnership formation and sustainability had been largely attributed to dishonesty, undue family interference, disagreement, etc. This could be greatly reduced if any partner found wanting at any time could be made to face disciplinary action at the Institution and compelled to compensate the other partner(s) and the firm by forfeiting some benefits as may be determined by the institution. This will greatly improve interest in partnership formation and consequently harness its benefits to the full.

\section{References}

Arrow, K. J., (1974). The Limits of Organization. New York: Norton.

Blau, P. M. and M. W. Meyer., (1987). Bureaucracy in Modern Society. 3d ed. New York: McGraw-Hill

Bloxham, E., (2002). Economic Value Management: Applications and Techniques, New Jersey, John Wiley \& Sons.

Camback, S., Samouel, P., and Price, D., (2006). Do Diseconomies of Scale Impact Firm Size and Performance? A Theoretical and Empirical Overview. Journal of Managerial Economics, 2006, Vol. 4, No. 1 (February), pp. 27-70

Capon, N., J. Farley and Hoenig H., (1990) 'Determinants of Financial Performance: A Meta Analysis', Management Science, October, pp. 1143-1159.

Child, J., (1973). Predicting and Understanding Organization Structure. Administrative Science Quarterly 18 (2): 168-185.

Cowling, K. and Waterson M., (1976) 'Price-Cost Margins and Market Structure', Economica, 43, 267-274.

Daft, R.L., (1997). Management, 4th ed., Florida, The Dryden Press

Ford, D., Gadde, L.-E., Håkansson, H. and Snehota, I. (2003). A Journal on Managing Business Relationships. John Wiley \& Sons Ltd, Chichester

Fortune. (1995b). The Fortune Global 500, Fortune, 7 August, 123-136, F1-F42.

Gradl, Christina and Beth Jenkins (2011). "Tackling Barriers to Scale: Fromlnclusive BusinessModels to Inclusive Business Ecosystems." Cambridge,MA: the CSR Initiative at the Harvard Kennedy School.

Grossman, S. J. and Hart. O. D., (1986). The Costs and Benefits of Ownership: A Theory of Vertical and Lateral Integration. Journal of Political Economy 94 (4): 691-719.

Hart, O. (1995). Firms, Contracts, and Financial Structure. Oxford: Clarendon Press.

Ifediora G.S.A., (2009). Appraisal Framework. 2nd Edition. Published by Institute for Development Studies, University of Nigeria, Enugu

Kimberly, J. R. (1976). Organizational Size and the Structuralist Perspective: A Review, Critique and Proposal. Administrative Science Quarterly 21 (4): 571-597.

Kocenda E. \& Svejnar J. (2003) Ownership and Firm Performance after Large-Scale Privatization JEL Classification: C33, D20, G32, $\mathrm{G} 34, \mathrm{~L} 20$

Kuye, O., (2011). Estate Office Practice. $2^{\text {nd }}$ Edition, Published by Adro Dadar Heritage Company Limited, Lagos, Nigeria

Leibenstein, H. (1976) Beyond Economic Man. Cambridge, MA: Harvard University Press.

Majumdar S. K. (1997). "The Impact of Size and Age on Firm-Level Performance: Some Evidence from India" Review of Industrial Organization 12: 231-241, Kluwer Academic Publishers.

Mansfield, Edwin. (1962). Entry, Gibrat's Law, Innovation, and the Growth of Firms. American Economic Review 52 (5):1023.

Parker, C. (2000). "Performance Measurement", Work Study 49(2), pp.63-66.

Pugh, D. S., D. J. Hickson, C. R. Hinings and C. Turner. (1969). The Context of Organization Structures. Administrative Science Quarterly 14 (1): 91-114.

Richardson, G. B. (1972). The Organisation of Industry. Economic Journal 82 (September): 883-896.

Robertson, D. H. (1923). The Control of Industry. London: Nisbet

Serrasqueiro, Z. S. and Paulo M. N. (2008). Performance and Size: Empirical Evidence from Portuguese SMEs. Small Business Economics 31 (2):195-217.

Shepherd,W. G. (1986) 'On the Core Concepts of Industrial Economics', in H.W. De Jong andW. G. Shepherd, eds, Mainstreams in 
Industrial Organization. Dordrecht: Martinus Nijhoff Publishers.

Symeou P. C. (2011) The Firm Size - Performance Relationship: An Empirical Examination of the Role of the Firm's Growth Potential JEL: D24, L11, L52, L96

Topak M. S. (2011) "The Effect of Board Size on Firm Performance: Evidence from Turkey" Journal of Middle Eastern Finance and Economics Issue 14 (2011), Euro Journals Publishing, Inc. 2011

Williamson O. E. (1975). Markets and Hierarchies: Analysis and Antitrust Implications. New York: Free Press.

Yang C. \& Chen K. (2009). Are Small Firms Less Efficient? Small Business Economics 32 (4):375-395

South-Africa Business Guide

Real Estate Dictionary (2004)

Financial \& Investment Dictionary (2006)

British Partnership Act 1890

Companies and Allied Matters Act, CAP 59, Laws of the Federation of Nigeria 1990

Nigeria Institution of Estate Surveyors and Valuers Directory of the Lagos State Branch 2012. 
